\title{
Effects of Leptin on Hydrogen Peroxide Induced Contractions in Isolated Human Umbilical Artery
}

\section{Izole Insan Umbilikal Arterinde Hidrojen Perokside Bağlı Kasılma Cevapları Üzerine Leptinin Etkisi}

Emine Dagtekin ${ }^{1}$, Ayse Saide Sahin²,

${ }^{1}$ Ministry of Health, Numune Hospital, Intensive Care Unit, Konya,

${ }^{2}$ Necmettin Erbakan University, Meram Faculty of Medicine, Department of Medical Pharmacology, Konya

Geliş Tarihi/Received: 19 June 2018 Kabul Tarihi/Accepted: 27 July 2018

\begin{abstract}
Öz
Amaç: Bu çalışmada izole insan umbilikal arterinin bazal tonusu ve hidrojen peroksid $\left(\mathrm{H}_{2} \mathrm{O}_{2}\right)^{\prime}$ e bağlı kasılma cevapları üzerine leptinin etkileri ve bu etkilerde nitrik oksitin rolü araştırılmıştır.

Gereçler ve Yöntem: Umbilikal arter halkaları sıcaklığı $37^{\circ} \mathrm{C}^{\prime}$ de sabit tutulan $\% 95 \mathrm{O}_{2}-\% 5 \mathrm{CO}_{2}$ karışımı ile gazlandırılan ve Krebs-Henseleit solüsyonu içeren $10 \mathrm{ml}$ 'lik izole organ banyolarına alındı. Uygulanan prosedürlere verilen cevaplar izometrik olarak kaydedildi.

Bulgular: Umbilikal arter halkalarının bazal tonusu üzerine leptinin etkilerinin araştırıldığı bölümde kümülatif tarzda banyoya uygulanan leptin $\left(10^{-11-10^{-7}} \mathrm{M}\right)$ dokuların bazal tonusunu etkilemedi. Benzer şekilde L-NAME $\left(10^{-4} \mathrm{M}\right)$ ile inkübe edilen dokularda da kümülatif leptin ilavesi dokuların bazal tonusunu değiştirmedi. Umbilikal arter halkalarında $\mathrm{H}_{2} \mathrm{O}_{2}\left(10^{-3} \mathrm{M}\right)$ ile maksimum kasılma cevabı alındıktan sonra organ banyosuna kümülatif olarak uygulanan leptin konsantrasyona bağımlı olarak gevşeme cevapları oluşturdu. Organ banyosuna $10^{-4} \mathrm{M}$ L-NAME ilave edilmesi $\mathrm{H}_{2} \mathrm{O}_{2}$ ' ye bağlı kasılma cevapları üzerine leptinin $10^{-11}$ ve $10^{-10} \mathrm{M}$ konsantrasyonlarında gözlenen gevşeme cevaplarını etkilemedi; leptinin $10^{-9}$ $10^{-8}$ ve $10^{-7} \mathrm{M}$ konsantrasyonlarda umbilikal arter seritlerine oluşturduğu gevşeme cevaplarını ise anlamlı olarak inhibe etti. Leptin ile inkübe edilen umbilikal arter halkalarında $\mathrm{H}_{2} \mathrm{O}_{2}$ ' nin etkilerinin araştırıldığı bölümde, dokuların $10^{-10} \mathrm{M}$ ve $10^{-7} \mathrm{M}$ leptin ile inkübe edilmesi kümülatif uygulanan $\mathrm{H}_{2} \mathrm{O}_{2}$ ' nin $\mathrm{pD}_{2}(-\log$ $E_{50}$ ) ve $E_{\max }$ değerlerini değiştirmedi.

Sonuç: Bu bulgular; insan umbilikal arterinde leptinin uygulanan tüm konsantrasyonlarında, $\mathrm{H}_{2} \mathrm{O}_{2}$ ' ye bağlı kasılma cevapları üzerine gevşetici etki oluşturduğunu, leptinin yüksek konsantrasyonlarında gözlenen gevşeme cevaplarına kısmen NO' in aracılık ettiğini; ayrıca umbilikal arterlerin bazal tonusu ve bazal tonus düzeyinde uygulanan $\mathrm{H}_{2} \mathrm{O}_{2}$ ' ye bağlı kasılma cevapları üzerinde leptinin inhibitör etki oluşturmadığını
\end{abstract} göstermektedir

Anahtar Kelimeler: Umbilikal arter, hidrojen peroksid, leptin

\section{Abstract}

Aim: In this study, effects of leptin on hydrogen peroxide induced contractions, basal tone of umbilical artery and role of nitric oxide were examined

Materials and Methods: Umbilical artery rings were placed in tissue bath containing Krebs-Henseleit Solution (KHS) gassed with $\% 95 \mathrm{O}_{2}$ and $\% 5 \mathrm{CO}_{2}$ at $37^{\circ} \mathrm{C}$. Responses to the applied procedures were recorded isometrically.

Results: In the part where the effects of leptin on basal tonus of umbilical artery rings were investigated, cumulative leptin $\left(10^{-11}-10^{-7} \mathrm{M}\right)$ did not affect basal tonus of tissues. Similarly, the cumulative leptin addition on tissues incubated with L-NAME $\left(10^{-4} \mathrm{M}\right)$ did not affect the basal tonus of the tissues. Cumulatively administered leptin in tissue bath after receiving maximal contraction with $\mathrm{H}_{2} \mathrm{O}_{2}\left(10^{-3} \mathrm{M}\right)$ on the umbilical artery rings produced relaxation responses concentration-dependent. Addition of $10^{-4} \mathrm{M}$ L-NAME to the tissue bath did not affect relaxation responses observed at concentrations $10^{-11}$ and $10^{-10} \mathrm{M}$ of leptin but significantly inhibited the relaxation responses observed at concentrations $10^{-9}, 10^{-8}$ and $10^{-7} \mathrm{M}$ of leptin on the umbilical artery strips on $\mathrm{H}_{2} \mathrm{O}_{2}$-induced contraction responses. In the part where the effects of $\mathrm{H}_{2} \mathrm{O}_{2}$ on leptin-induced umbilical artery rings, incubation of the tissues with $10^{-10} \mathrm{M}$ and $10^{-7} \mathrm{M}$ leptin did not change $\mathrm{pD}_{2}\left(-\log \mathrm{EC}_{50}\right)$ and $\mathrm{E}_{\max }$ values of cumulative applied $\mathrm{H}_{2} \mathrm{O}_{2}$.

Conclusion: These results demonstrate that a relaxant effect on $\mathrm{H}_{2} \mathrm{O}_{2}$-induced contraction response in all concentrations of leptin in human umbilical artery and relaxation responses observed at high concentrations of leptin are partially mediated by $\mathrm{NO}$ and also demonstrate that leptin does not have an inhibitory effect on $\mathrm{H}_{2} \mathrm{O}_{2}$-induced contraction responses applied at basal tone and basal tonus levels of umbilical arteries.

Key words: Umbilical artery, hidrogen peroxide, leptin

\section{INTRODUCTION}

Leptin is a hormone with anorexigenic effect, which is released by fat cells in the body, diminishing appetite and evoking the fat burning (1). In addition, it also plays an important role in the maintenance of homeostasis in the cardiovascular and urinary systems, regulation of hypothalamic-hypophyseal functions, insulin resistance, neuroendocrine system and regulation of immune functions (2). In vitro studies conducted with leptin which is a multifunctional hormone have shown its vasoactive effects on various vascular beds $(3,4)$.

Since the umbilical cord has no autonomous innervation, endogenous orexogenous vasoconstrictor or vasodilator substances play an important role in the control of fetoplacental vascular tonus (5). Leptin released by the fetal tissues and placenta in pregnant 
women is also known to be found in the blood samples collected from the umbilical artery and vein at a level increasing with gestational duration $(6,7)$.

Hydrogen peroxide $\left(\mathrm{H}_{2} \mathrm{O}_{2}\right)$ forms by the enzymatic or spontaneous degradation of superoxide anions that are side products of oxidases, and is found widely in human body $(8,9)$. It has been shown that physiological $\mathrm{H}_{2} \mathrm{O}_{2}$ concentration in human body is about $300 \mu \mathrm{m}$, and the concentration may reach millimolar levels in the cases of increased oxidative stress (10). $\mathrm{H}_{2} \mathrm{O}_{2}$ is an important substance in the development of oxidative stress related functional and metabolic dysfunctions, because it can easily pass through the cell membrane and form hydroxyl radicals that are highly potent (11). Therefore, addition of $\mathrm{H}_{2} \mathrm{O}_{2}$ to the medium is used as an oxidative stress model in experimental studies (12). Studies have shown that $\mathrm{H}_{2} \mathrm{O}_{2}$ contraction or relaxation varies depending on species, vascular bed, and contractile status (13-14). In the present study, the direct effects of leptin on the basal level or precontracted with $\mathrm{H}_{2} \mathrm{O}_{2}$, and the role of nitric oxide (NO) on these effects were investigated in the human umbilical cord arteries.

\section{MATERIALS AND METHODS General}

Umbilical cord samples separated as medical waste in the Gynecology and Obstetrics Department were used in this study which was approved by the Non-Pharmaceutical and Medical Device Research Ethics Committee (Decision No: 2017/782). The arteries isolated from the umbilical cords that were brought to the laboratory within the cold KrebsHenseleit Solution (KHS) were cleaned from the surrounding tissues, and ring preparates of $3-4 \mathrm{~mm}$ width were prepared. The rings were suspended isolated tissue baths filled $10 \mathrm{ml}$ of KHS continuously bubbled with a mixture of $95 \% \mathrm{O}_{2}$ and $5 \% \mathrm{CO}_{2}$ at $37^{\circ} \mathrm{C}$. At the beginning of the experiment, the rings were stretched to an initial tension of $1 \mathrm{~g}$ and allowed to equilibrate for 60 min in KHS, which was changed every $15 \mathrm{~min}$. The responses received against the applied agents at the end of the resting period were isometrically (Commat, Ankara, TURKEY) recorded using a transducer (BIOPAC MP36, California USA).

\section{Experimental Procedure}

Effects of leptin on basal tonus in the umbilical cord rings were investigated in first group. After control contraction with $10^{-3} \mathrm{M} \mathrm{H}_{2} \mathrm{O}_{2}$, the tissues were washed until resting tone was re-established. Concentrationresponse curves for leptin $\left(10^{-11} \mathrm{M}-10^{-7} \mathrm{M}\right)$ were obtained by cumulative addition to the organ bath. Some tissues were incubated with the nitric oxide synthase inhibitor N $\omega$-Nitro-L-arginine methyl ester (L-NAME, 10-4 M) for 20 min. before leptin addition.

To evaluate the effect of leptin on $\mathrm{H}_{2} \mathrm{O}_{2}$-induced contraction, the rings were contracted with $10^{-3}$ $\mathrm{M} \mathrm{H}_{2} \mathrm{O}_{2}$. After maximal contractile response was achieved, increasing concentrations of leptin (10${ }_{11} \mathrm{M}-10^{-7} \mathrm{M}$ ) were added cumulatively to the bath. Some of rings were incubated for $20 \mathrm{~min}$. with $10^{-4}$ M L-NAME before a concentration response curve to leptin was recorded.

In the other study groups, we investigated the $\mathrm{H}_{2} \mathrm{O}_{2}$ induced contraction responses in the tissues incubated with leptin. For this purpose, after cumulative response curves with $\mathrm{H}_{2} \mathrm{O}_{2}\left(10^{-9}-10^{-3} \mathrm{M}\right)$ were obtained, the tissues were washed until resting tone was re-established. 10-10 M leptin was added to the medium and incubation was performed for 20 min. before the second concentration-response curve with $\mathrm{H}_{2} \mathrm{O}_{2}$ was obtained. The same procedure was repeated with $10^{-7} \mathrm{M}$ leptin.

Drugs and solutions: Human Recombinant Leptin (Sigma); Hydrogen Peroxide $\left(\mathrm{H}_{2} \mathrm{O}_{2}\right.$, Merck); $\mathrm{N} \omega$ Nitro-L-arginine methyl ester (L-NAME, Sigma)

Krebs-Henseleit Solution (KHS) [mM]: $\mathrm{NaCl} 118.3$; $\mathrm{KCl}$ 4.69; $\mathrm{KH}_{2} \mathrm{PO}_{4}$ 1.18; $\mathrm{CaCl}_{2}$ 1.25; $\mathrm{MgSO}_{4}$ 1.17; $\mathrm{NaHCO}_{3} 25.0$; Glucose 11.1

\section{Statistical Analysis}

The responses received to the applied agents in the study were evaluated as percent (\%) of the maximum contraction response obtained with $10^{-3} \mathrm{M} \mathrm{H}_{2} \mathrm{O}_{2}$ Emax (the percentage of maximal response of the tissue) and $\mathrm{pD}_{2}$ (negative log value of molar concentration producing contraction by $50 \%$ ) were calculated. Statistical analysis of the data was performed using a computer software package (SPSS Statistics, version 17.0 (SPSS Inc., Chicago, IL, USA) program. The data were expressed as mean \pm standard deviation (SD). The Shapiro-Wilk's test was applied to check that assumptions of normality were met. The data all of which were obtained from continuous numerical variables were normally distributed, and so, independent samples Student t-test was performed for comparing two independent groups. Results were considered significant if $p<0.05$.

\section{RESULTS}

$\mathrm{H}_{2} \mathrm{O}_{2}\left(10^{-3} \mathrm{M}\right)$ produced sustained contraction in umbilical artery rings. These contractions were reproducible and time-dependent changes were 
Table 1. Effects of leptin in human umbilical artery precontracted with hydrogen peroxide $\left(\mathrm{H}_{2} \mathrm{O}_{2} ; 10^{-3} \mathrm{M}\right)$; control $(n=8)$ and in the presence of $\mathrm{N}^{\mathrm{w}}$-nitro-L-arginine methyl ester (L-NAME; $\mathrm{n}=8$ )

\begin{tabular}{llllll}
\hline & Leptin $\mathbf{1 0}^{-11} \mathbf{M}$ & Leptin $10^{-10} \mathbf{M}$ & Leptin10 $0^{-9} \mathbf{M}$ & Leptin10 $\mathbf{1 0}^{-8} \mathbf{M}$ & Leptin10 $^{-7} \mathbf{M}$ \\
\hline Control & $95.12 \pm 4.94^{*}$ & $88.50 \pm 5.90^{*}$ & $78,62 \pm 5.65^{*}$ & $72.00 \pm 6.92^{*}$ & $59.75 \pm 10.37^{*}$ \\
L-NAME & $95.87 \pm 4.32$ & $91.37 \pm 7.30$ & $88.75 \pm 8.64^{* *}$ & $84.7 \pm 1.87^{* *}$ & $77.25 \pm 10.06^{* *}$ \\
\hline
\end{tabular}

Results are expressed as the percent of contraction induced by $\mathrm{H}_{2} \mathrm{O}_{2}$

* Significantly different from contraction induced $10^{-3} \mathrm{M} \mathrm{H}_{2} \mathrm{O}_{2}(\mathrm{p}<0.05)$

** Significantly different from control leptin $(p<0.05)$

not observed. In the study part where effects of leptin on the basal tonus of the umbilical cord rings were investigated; leptin $\left(10^{-11}-10^{-7} \mathrm{M}\right)$ which was cumulatively added to the bath did not affect basal tonus of the tissues. Similarly, cumulative leptin addition did not change basal tonus of the tissues that were incubated with L-NAME.

Relaxing effects of leptin on the umbilical cord rings contracted with $\mathrm{H}_{2} \mathrm{O}_{2}$ were studied in the other group. Leptin $\left(10^{-11}-10^{-7} \mathrm{M}\right)$ administered to the preparations at the plateau of maximal contraction to $\mathrm{H}_{2} \mathrm{O}_{2}$, induced relaxation in a concentration dependent manner $(p<0.05 n=8$; Table 1; Figure 1). Addition of $10^{-4} \mathrm{M} \mathrm{L-NAME}$ to the organ bath, did not affect the relaxation responses observed in $10^{-11}$ and $10^{-10} \mathrm{M}$ concentrations of leptin, on $\mathrm{H}_{2} \mathrm{O}_{2}$ induced contraction responses. Whereas it significantly decreased the relaxation responses produced in the umbilical cord strips at $10^{-9}, 10^{-8}$ and $10^{-7} \mathrm{M}$ concentrations of leptin $(p<0.05 n=8$; Table 1; Figure 1).

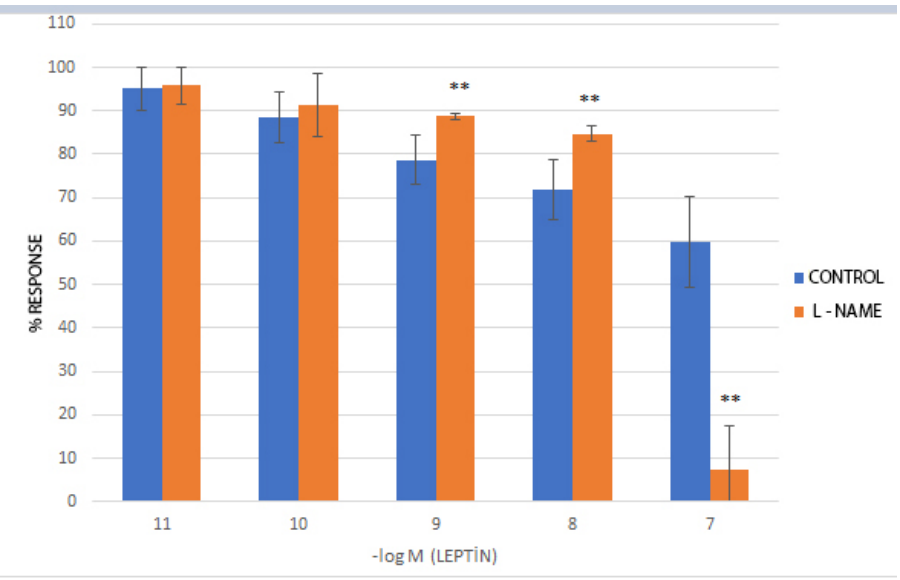

Figure 1. Effects of leptin in human umbilical artery precontracted with hydrogen peroxide $\left(\mathrm{H}_{2} \mathrm{O}_{2} ; 10^{-3} \mathrm{M}\right)$; control $(n=8)$ and in the presence of $\mathrm{N}^{\mathrm{w}}$-nitro-L-arginine methyl ester (L-NAME; $n=8$ )

Results are expressed as the percent of contraction induced by $\mathrm{H}_{2} \mathrm{O}_{2}$

** Statistically significant $(p<0.05)$ difference with compared with control
Leptin was used at concentrations of $10^{-10}$ and $10^{-7} \mathrm{M}$ in the study part where effects of $\mathrm{H}_{2} \mathrm{O}_{2}$ were investigated in the umbilical artery rings incubated with leptin. Cumulatively applied $\mathrm{H}_{2} \mathrm{O}_{2}\left(10^{-9}-10^{-3} \mathrm{M}\right)$ produced reproducible contraction responses that showed no time related change, in the umbilical artery rings. Incubation of the tissues with $10^{-10} \mathrm{M}$ and $10^{-7} \mathrm{M}$ leptin did not change $\mathrm{pD}_{2}\left(-\log \mathrm{EC}_{50}\right)$ and $\mathrm{E}_{\max }$ values of cumulatively administered $\mathrm{H}_{2} \mathrm{O}_{2}(p>0.05, n=7$ Table 2).

\section{DISCUSSION}

In the present study conducted on isolated umbilical artery; leptin did not change basal tonus of the tissues, but it produced relaxation in the precontracted arteries with $\mathrm{H}_{2} \mathrm{O}_{2}$. Addition of leptin to the medium at two different concentration did not change the contractions responses obtained with cumulatively applied $\mathrm{H}_{2} \mathrm{O}_{2}$.

Human placenta has no autonomous innervation during the fetal circulation (15). Therefore, endogenous or exogenous substances influencing umbilical artery tonus are important for the regulation of umbilicalplacental circulation and development of the fetus (5). It has been demonstrated that, besides adipose tissue leptin which is a vasoactive hormone was also released by fetal tissues and placenta in pregnant women, and was found in the blood samples collected from the umbilical artery and vein at an increasing level during gestation $(6,7)$.

In the present study, leptin produced concentration dependent relaxation responses in the umbilical artery rings that were pre-contracted with $\mathrm{H}_{2} \mathrm{O}_{2}$. This result indicates that leptin causes a relaxing effect on oxidative stress related contraction responses in human umbilical cord. Consistently with our

Table 2. $\mathrm{E}_{\max }$ and $\mathrm{pD}_{2}\left(-\log \mathrm{EC}_{50}\right)$ values for $\mathrm{H}_{2} \mathrm{O}_{2}\left(10^{-9}-10^{-3}\right.$ $\mathrm{M})$ in human umbilical artery incubated with leptin.

\begin{tabular}{lll}
\hline & Leptin $1 \mathbf{0}^{-10} \mathbf{M}$ & ${\text { Leptin } 10^{-7} \mathbf{M}}^{-10}$ \\
\hline $\mathrm{Emax}_{2}$ & $102.57 \pm 7.09$ & $103.71 \pm 10.09$ \\
$\mathrm{pD}_{2}$ & $5.323 \pm 0.34$ & $5.768 \pm 0.581$
\end{tabular}

Results are expressed as the percent of contraction induced by $\mathrm{H}_{2} \mathrm{O}_{2}$ $\left(10^{-3} \mathrm{M}\right)$ 
results, $1 \mu \mathrm{M}$ leptin administration in the human internal mammarian artery rings contracted with norepinephrine produced relaxation (16). Similarly, leptin induced concentration dependent vasodilatation in isolated Wistar rat, weak Zucker rat and Mongrel dog coronary arterioles (17).

It is known that NO is produced by nitric oxide synthase enzyme, in endothelial cells and relaxes vessels by stimulating guanylate cyclase in underlying smooth muscle cells (18). The presence of leptin receptors has been shown in the vascular smooth muscle and endothelial cells (19), and the role of endothelial factors in leptin dependent vasodilatation has been studied. In a study on rabbit aortic rings that were contracted with phenylephrine $\left(10^{-6} \mathrm{M}\right)$, leptin was administered within $10^{-12}-10^{-9}$ $\mathrm{M}$ concentration range, and $\mathrm{NO}$ has been shown to mediate the occurred vasodilatation (20). In another study with isolated rat aorta, injury to the endothelial layer eliminated the relaxation response to leptin in the tissue contracted with phenylephrine, and $10^{-4} \mathrm{M}$ NO synthase inhibitor L-NAME inhibited leptin related relaxation responses (21). Similarly, NO dependent relaxation responses occurred in rat mesenteric artery which was contracted with phenylephrine (22). In the present study, incubation of the umbilical artery rings with L-NAME did not affect the relaxation responses obtained at low concentrations of leptin $\left(10^{-11}\right.$ ve $\left.10^{-10}\right)$, while it caused a partial, but significant inhibition of the relaxation responses obtained at $10^{-9}-10^{-7} \mathrm{M}$ concentrations leptin. These results show that relaxation responses observed at high concentrations of leptin on oxidative stress related contraction responses in human umbilical artery are partially mediated by NO. On the contrary, in a study with human saphenous vein or internal mammarian artery, injury to the endothelial layer or inhibition of NO synthesis did not affect leptin induced relaxation responses. The authors suggested that leptin also activates endothelium independent mechanisms (23). Human recombinant leptin was applied at $10^{-13}-5 \times 10^{-}$ ${ }_{10} \mathrm{M}$ dose range in rat aortic and mesenteric artery rings that were pre-contracted with phenylephrine (10$6 \mathrm{M})$, and dose dependent relaxation responses were observed. Leptin dependent vasodilatation which occurred in the aortic rings was blocked with $3 \times 10^{-4}$ M L-NAME, but L-NAME did not show inhibitor effect in the mesenteric artery (4). In a study investigating the effects of leptin on the circulation of forearm in humans, intra-arterial leptin infusion was performed in the presence and absence of NO synthase inhibitor.
Leptin infusion of 1,10 and $100 \mathrm{ng} / \mathrm{kg} / \mathrm{min}$ caused a significant increase in blood flow and a significant decrease in vascular resistance of the forearm. The authors argued that leptin produced vasodilatation with a NO independent mechanism (24).

In the present study, cumulatively applied leptin did not affect basal tonus of human umbilical artery. In addition; incubation of the tissues at basal tonus level with low and high concentrations of leptin did not affect the contraction responses received with $\mathrm{H}_{2} \mathrm{O}_{2}$. Incubation of the umbilical artery rings with L-NAME in addition to leptin did not change these results in both study groups. $1 \mu \mathrm{M}$ leptin did not lead to a significant change on basal tonus also in the isolated human internal mammarian artery rings (6). Lembo et al. demonstrated that leptin induced a slight decrease in basal tone in rat aortic and mesenteric rings (4).

On the contrary to these studies, in a study conducted on the pulmonary artery and thoracic aorta of spontaneously hypertensive rats, cumulatively administered leptin induced more contractions in the thoracic aorta compared to the pulmonary artery (25). In another study, incubation of isolated rat aortic smooth muscle cells with $10^{-7} \mathrm{M}$ leptin for 48 hours increased the binding of endothelin-1 to the smooth muscle cells after the 12th hour. Whereas an increase was found in the ETAR protein level in the smooth muscle cells in the presence of $10^{-9}-10^{-7} \mathrm{M}$ leptin. It was proposed that, leptin may cause vasoconstriction, because it caused elevation in endothelin-1 level within the range of these concentrations (26).

In summary; the present results suggest that leptin exerts a relaxant effects on $\mathrm{H}_{2} \mathrm{O}_{2}$ induced contractile responses at all applied concentrations in human umbilical artery, and the relaxation responses observed at high concentrations of leptin were partially mediated by NO. In addition, leptin has no inhibitory effect on $\mathrm{H}_{2} \mathrm{O}_{2}$ induced contractions at basal tone and basal tonus levels of umbilical arteries.

Conflict of interest: Authors declare that there is no conflict of interest between the authors of the article.

Financial conflict of interest: Authors declare that they did not receive any financial support in this study.

Address correspondence to: Ayse Saide Sahin, Necmettin Erbakan University, Meram Faculty of Medicine, Department of Medical Pharmacology, Konya,

Phone: 05422575176 e-mail: aysesaide@gmail.com

\section{REFERENCES}

1. Ahima RS, Flier JS. Leptin. Annu Rev Physiol 2000;62:413- 
37.

2. Comba A, Mert H, Comba B. Leptin ve metabolik etkileri. YYU Vet Fak Der 2014;25:87-91.

3. RodriguezA, Fortuno A, Gomez-Ambrosi J et al. The inhibitory effect of leptin on angiotensin II-induced vasoconstriction in vascular smooth muscle cells is mediated via nitric oxide dependent mechanism. Endocrinology 2007;148:324-31.

4. Lembo G, Vecchione $C$, Fratta $L$, et al. Leptin induces direct vasodilation through distinct endothelial mechanism, Diabetes 2000;49:293-7.

5. Rodriguez I and Gonzalez M. Physiological mechanisms of vascular response induced by shear stress and effect of exercise in systemic and plasental circulation. Front Pharmacol 2014;5:209.

6. Yoshimitsu N, Douchi T, Kamio M, et al. Differences in umbilical venous and arterial leptin levels by mode of delivery. Obstetrics \&Gynecology 2000;96:342-5.

7. Mouzo SH, Lepercq J, Catalano P. The known and unknown of leptin in pregnancy. Obstetrics \& Gyncology 2006;194,153745.

8. Ray DP, Huang BW, Tsuji Y. Reactive oxygen species (ROS) homeostasis and redox regulation in cellular signaling. Cell Signal 2012;24:981-90.

9. Park WH. The effects of exogenous $\mathrm{H}_{2} \mathrm{O}_{2}$ on cell death, reactive oxygen species and glutathione levels in calf pulmonary artery and human umbilical vein endothelial cells. Int J Mol Med 2013;31:471-6.

10. Barlow RS, White RE. Hydrogen peroxide relaxes porcine coronary arteries by stimulating BKCa channel activity. Am J Physiol 1998;275:H1283-9.

11. Duman İ, Doğan N. Vazoactive effects of oxidative stress elicited by hydrogen peroxide in the human umbilical artery: An in vitro study. Pharmacology \& Pharmacy 2011;2:347-53.

12. Şahin AS, Görmüş N, Duman A. Preconditioning with levosimendan prevents contractile dysfunction due to $\mathrm{H}_{2} \mathrm{O}_{2}-$ induced oxidative stres in human myokardium. J Cardiovasc Pharmacol 2007;50:419-23.

13. Rodriguez-Martinez MA, Garcia-Cohen EC, Baena B J, et al. Contractile responses elicited by hydrogen peroxide in aorta from normotensive and hypertensive rats. Endothelial modulation and mechanism involved. $\mathrm{Br} \mathrm{J}$ Pharmacol 1998;125:1329-35.

14. Matsuda K, Teragawa $H$, Fukuda $Y$, et al. Leptin causes nitric oxide independent coronary artery vasodilation in humans. Hypertens Res 2003;26:147-52.

15. Fox SB, Khong TY. Lack of innervation of human umbilical cord. An Immunohistological and histochemical study. Plasenta 1990;11(1):59-62.

16. Burma O, Ozcan M, Kacar E, ve ark. In vitro effects of sodium nitroprusside and leptin on norepinephrine-induced vasoconstriction in human internal mammary artery. Cardiovasc J Afr 2015;26:4-7.

17. Knudson JD and et al. Leptin receptors are expressed in coronary arteries, and hyperleptinemia causes significant coronary endothelial dysfunction. Am J Physiol 2005;289:H4856.

18. Ignarro LJ, Lippton $\mathrm{H}$, Edwards JC, et al. Mechanism of vascular smooth muscle relaxation by organic nitrates, nitrites, nitroprusside and nitric oxide: Evidence for the involvement of S-nitrosothiols as active intermediates 1981;218:739-49.

19. Papadopoulos DP, Makris K, Krepsi PG, et al. Human soluble leptin receptor number in healthy normotensive individuals with high normal blood pressure. Am J Hypertens 2005;18:1001-4.

20. Şahin AS, Barışkaner $H$. The mechanism of vasorelaxant effect of leptin on isolated rabbit aorta. Fundamental \& Clinical Pharmacology 2007;21:595-600.

21. Kimura K, Tsuda K, Baba A, et al. Involvement of nitric oxide in endothelium-dependent arterial relaxation by leptin. Biochemical and Biophysial Research Communications 2000;273:745-9.

22. Jamroz-Wishiewska A, Gertler A, Solomon G, et al. Leptininduced endothelium-dependent vasorelaxation of peripheral arteries in lean and obese rats: Role of nitric oxide and hydrogen sul de. PLoS ONE 2014;9(1):1-14.

23. Momin AU, Melikian N, Shah AM, et al. Leptin is an endothelialindependent vasodilator in humans with coronary artery disease: Evidence for tissue speci city of leptin resistance. Eur Heart J 2006; 27: 2294-9.

24. Nakagawa K, Higashi Y, Sasaki S, et al. Leptin causes vasodilation in humans. Hypertens Res 2002;25:161-5.

25. Gomart S, Gaudreau-Menard C, Jespers P, et al. Leptininduced endothelium-independent vasoconstriction in thoracic aorta and pulmonary artery of spontaneously hypertensive rats: Role of calcium channels and stores. PLoS ONE 2017;12(1):1-18.

26. Juan CC, Chuang TY, Lien CC, et al. Leptin increases endotelin type A receptor levels in vascular smooth muscle cells. Am J Physiol Endocrinol Metab 2008;294:E481-7. 